\title{
Digital transformation in tourism: Examining the perspectives of hotel managers*
}

\section{Turizmde dijital dönüşüm: Otel yöneticilerinin bakış açılarının incelenmesi}

Gönderim Tarihi / Received : 12.12.2020

Kabul Tarihi / Accepted $\quad$ : 16.05.2021

Doi: https://doi.org/10.31795/baunsobed.839805

Aslınur YAVUZ ${ }^{\text {*े }}$ Muammer MESCi²

\begin{abstract}
This study aims to determine the perspectives of hotel managers on digital transformation in tourism and to evaluate the activities of hotel enterprises related to digital transformation. In this context, the qualitative research method was used in the research, and data were obtained by semi-structured interviews. Descriptive analysis method was used to analyze the data obtained from the participants. As a result of the research, it was found that digital transformation will make a significant contribution to the tourism sector, provide new alternatives and it is vital for the tourism sector to support digital transformation. Also, it has been determined that during the transition to digital transformation, there may be challenges, especially in transferring innovation to staff and customers. However, in addition to this work, which focuses on managers' point of view, suggestions have been made that research related to digital tourism can be carried out from the customer's point of view, while various studies can be carried out so that accommodation businesses can transfer digital applications in their companies to the customer with effective promotions and advertising.
\end{abstract}

Keywords: Digital, Digital transformation, Digital tourism.

\footnotetext{
"Bu çalışma, birinci yazar Aslınur Yavuz'un ikinci yazar Prof.Dr.Muammer Mesci'nin danışmanlığında tamamladığ1 “Turizmde Dijital Dönüşüm: Otel Yönetcilerinin Bakış Açılarının İncelenmesi” isimli yüksek lisans tezinden türetilmiştir. Bu çalışmanın etik kurul kararı alınmıştır.

${ }^{*}$ Sorumlu Yazar / Corresponding Author

${ }^{1}$ Bilim Uzmanı, Düzce Üniversitesi/Sosyal Bilimler Enstitüsü/Toplam Kalite Yönetimi/Toplam Kalite Yönetimi Anabilim Dalı, aslinurr_yavuzz@hotmail.com, https://orcid.org/0000-0002-5646-8468

${ }^{2}$ Prof. Dr., Düzce Üniversitesi/Akçakoca Turizm İşletmeciliği ve Otelcilik Yüksekokulu/ Turizm İşletmeciliği ve Otelcilik / Turizm İşletmeciliği ve Otelcilik Anabilim Dalı,

muammermesci@duzce.edu.tr, https://orcid.org/0000-0002-3053-3954
} 
ÖZ: Bu çalışmanın amacı, turizmde dijital dönüşüme otel yöneticilerinin bakış açılarını belirlemek ve otel işletmelerinin dijital dönüşümle ilgili hangi faaliyetleri gerçekleştirdiklerini değerlendirmektir. Bu bağlamda araştırmada nitel araştırma yöntemi kullanılmış olup yarı yapılandırılmış görüşme tekniği ile veriler elde edilmiştir. Görüşme sonucunda katılımcılardan elde edilen veriler betimsel analiz yöntemi ile analiz edilmiştir. Araştırma sonucunda dijital dönüşümün, turizm sektörüne önemli katkılar sağlayacağı, yeni alternatifler sunacağ 1 ve turizm sektörünün dijital dönüşümü desteklemesinin önemli olduğu ortaya konulmuştur. Ayrıca, dijital dönüşüme geçiş sürecinde özellikle personel ve müşteriye yeniliği aktarabilmek konusunda güçlüklerin oluşabileceği belirlenmiştir. Bununla birlikte, yöneticilere yönelik yapılan bu çalışmanın yanı sıra müşteri açısından dijital turizm ile ilgili araştırma gerçekleştirilebileceği, konaklama işletmeleri ise etkili tanıtımlarla ve reklamlarla işletmelerindeki dijital uygulamaları müşteriye aktarabilmesi için çeşitli çalışmalar yapılabileceği yönünde öneriler sunulmuştur.

Anahtar Kelimeler: Dijital, Dijital dönüşüm, Dijital turizm. 


\section{GENIŞLETİLMIŞ ÖZET}

\section{Literatür taraması}

Turizm dünyayı şekillendiren önemli bir sektör olarak kabul edilmekte ve gelişmeyle ilişkilendirilmektedir (Giampiccoli ve Saayman, 2014: 1667). Turizm sektöründe bilgi kullanımının yoğunlaşması, yeni teknolojilerin kullanımını da beraberinde getirmiş ve turizm için dijital dönüşümde kaçınılmaz olmuştur (Benckendorff vd. 2014; Koo vd., 2015: 100).

Yeni bir çağ olan Endüstri 4.0 insaların yaşam tarzında, ekonomide ve toplumsal olarak da değişiklikleri bereberinde getirmektedir. Sosyal medya, yapay zeka ve yeni nesil dijital uygulamalar günümüzde çok fazla kullanılmaya başlanmıştır. Teknolojinin hızla ilerlemesi ile birlikte teknoloji kullanımı insanların yaşamlarına derinlemesine etki etmektedir. Teknoloji kullanılmasındaki diğer önemli durum ise seyahat planlanmasını ve seyahati daha konforlu hale getirmesidir (Bahar vd., 2019: 74). Dijital dönüşüm süreci işletmelere sürdürülebilirliklerini başarılı bir şekilde devam ettirebilme şansı sağlayabilmektedir. İçinde bulunduğumuz asrın son zamanlarında teknolojik, ekonomik ve sosyal alanda devrim özelliğine sahip önemli değişimler yaşanmaktadır. Bu değişimlerin en temelinde hiç şüphesiz üstün teknolojik gelişmelerdir. Gerçeği artıran mobil uygulamalar müşteri deneyimini kişiselleştirmekte ve özellikle $\mathrm{Z}$ kuşağının turizm hareketliliğinde sık bulunmasını yeni nesil teknolojilere uyma hızı arttırmaktadır. Bu bağlamda da "Toplum 5.0 olarak adlandırılan akıllı turist kavramıda ortaya çıkmaktadır" (Palumbo vd., 2013).

Giderek hız kazanan küreselleşme ve değişen teknoloji, işletmelerin artan rekabet ortamında güçlü kalmaları için önemlidir. Ayrıca bunlara ek olarak, sürekli değişen müşteri talepleri ve ihtiyaçlarının da eklenmesi yeni planlar oluşturulmasını gerekli kılmıştır (Yeşilot ve Dal, 2019: 265). Müşterilerle birebir ilişki kurulmasında, son dönemde özellikle akıllı telefonlarda aplikasyon uygulamalarının kullanılmaya başlaması, mobil uygulamaların teşvik edilmesi, navigasyon uygulamaları, mobil ödeme sistemlerinin kullanılmaya başlanmas1, sosyal paylaşım sitelerinin ve diğer sitelerin mobile uyumu gibi gelişmeler müşteri deneyimi için önemlidir. Dolayısıyla müşteri deneyimi geliştirilirken bilgi teknolojileri de göz önüne alınmalıdır. Tüm bunlardan yola çıarak turizm faaliyetleriyle ekonomik kalkınma ve çevresel değerlerin korunması, hatta bu değerlerin artırılması için dijital dönüşümü sağlamak ve sürdürülebilir hale getirmek temel amaç olmalıdır. Bu durumda, dijital dönüşüm süreci işletmelere sürdürülebilirliklerini başarılı bir şekilde devam ettirebilme şansı sağlayabilecektir (Dirsehan,2012: 66). 


\section{Yöntem}

$\mathrm{Bu}$ çalışmanın amacı, turizmde dijital dönüşüme otel yöneticilerinin bakış açılarını belirlemek ve otel işletmelerinin dijital dönüşümle ilgili hangi faaliyetleri gerçekleştirdiklerini değerlendirmektir. Çalışmada nitel araştırma yöntemi kullanılmış ve araştırma verileri yarı yapılandırılmış görüşmelerle elde edilmiştir. Görüşmede yer alan orta, üst ve lüks segment otel yöneticilerinden önceden randevu alınmış ve ayarlanan tarihte görüşmeler gerçekleştirilmiştir. Görüşmeler 1 Mayıs 2020 ile 25 Temmuz 2020 tarihleri arasında yapılmıştır. Ayrıca görüşmeler güvenilirliğin sağlanması için mülakat yapılan katılımc1ların ifadeleri yazılı olarak kaydedilmiştir. Bunun yanı sıra, katılımcıların cevaplarına Covid-19 salgını sebebiyle elektronik posta yoluyla ulaşıldı̆̆ için ifadelerine ilişkin yazılı notlar dijital olarak da kayıt altına alınmıştır. Bu görüşmeler sonucu 18 görüşme formundan 72 sayfalık veri elde edilmiştir.

\section{Bulgular ve tartışma}

Araştırma da dijital dönüşümün turizm sektörüne önemli katkılar sağlayacağı, yeni alternatifler sunacağ 1 ve turizm sektörünün dijital dönüşümü desteklemesinin önem taşıdı̆̆ı tespit edilmiştir. Ayrıca, dijital dönüşüme geçiş sürecinde, özellikle inovasyonun personele ve müşterilere aktarılması konusunda zorluklar olabileceği belirlenmiştir. Araştırmada yurtiçi/yurtdışı bilgi teknolojilerinin takibi konusunda ise dünyadaki güncel uygulamaların takip edilmesinin işletmelere olumlu geri dönüşler sağlayacağı düşünülmektedir. Araştırmada elde edilen bir diğer bulguda dijital dönüşümle siber saldırılara dikkat edilmesi gerektiği ve kötü niyetli uygulamalarla mücadelede geleneksel yöntemlerin yerine, yenilikçi yöntemlerin kullanılmaya başlanmasının işletmelere katkı sağlayabileceği yönündedir. Dahil olunan yada olmayı düşünülen bilgi teknolojileri kapsamında ise işletmeler farklı bilgi iletişim kanallarını kullanması hem destinasyonun pazarlanması ve işletmenin geliştirilmesi açısından hem de rekabetçiliğin artmasını sağlaması açısından önemli olacağı düşünülmektedir. Mevcut altyapı konusunda, turizm işletmelerinin, ülkeler veya bölgelerin sektördeki başarılarını attırmak için dijitalleşme alt yapının geliştirmesi gerektiği ve otel işletmelerin, dijital uygulamalarını kusursuz aktarabilmeleri için alt yapılarının güçlü olması önemli olduğu anlaşılmaktadır.

\section{Sonuç ve öneriler}

Çalışma sonucunda dijital dönüşümü sağlamak için, otel işletmelerinin her yönüyle uygun potansiyeli taşıması için belirli dijital uygulamaların ve bilgi teknolojilerinin hali hazırda mevcut olduğu sonucuna ulaşılmıştır. Ancak bu konuyla ilgili detaylı çalışma ve uygulamaların incelenmesi gerekmektedir. Ayrıca katılımcıların ifadelerinde turizmde dijital dönüşüm sağlanması için otel işletmelerinin her yönden uygun potansiyeli taşıdığı ve belirli dijital uy- 
gulamaların, bilgi teknolojilerinin hali hazırda olduğunu belirtmişlerdir. Fakat konu ile ilgili detaylı çalışmaların ve uygulamaların incelemesinin yapılması gerektiği ve dijital dönüşümün turizm sektöründe sağlanması için zamana ihtiyaç olduğu yönünde olmuştur. Dijitalleşme, turizm işletmelerinin, ülkeler veya bölgelerin sektördeki başarılarını attırmak için önemli bir adım olacağı düşülmektedir. Bu yüzden işletmelerin, dijital uygulamalarını kusursuz aktarabilmeleri için alt yapılarının güçlü olması önem arz etmektedir. Bu bağlamda da işletmelerde her ne kadar gerekli alt yapı olsada bazı hizmetlerde alt yapı yetersizliği olduğu bu konuda detaylı altyapı incelemelerinin yapılması gerektiği sonucuna ulaşılmaktadır. Ayrıca çalışma sonucunda uyum sürecinin önemli bir güçlük olduğuna özellikle personel ve müşteriye yeniliği aktarabilmek konusunda güçlükler yaşanacağına dikkat çekilmiştir. Uyum süreci aslında kişinin sahip olduğu özellikleri ile bulunduğu ortam içerisinde uyumlu ilişkiler oluşturması ve bunu devam ettirebilmesidir. Buradan yola çıkarak müşteri ve teknolojiyi dengeleyerek uyum sürecinin temelinin oluşturabileceği düşünülmektedir. Tüm bunlardan yola çıkarak araştırmacılar, dijital turizm alanında yapılmış çalışmalardan faydalanarak, dijital dönüşümün daha büyük ölçekte olduğu işletmelerde sektörel bazda inceleme çalışması yapılabilir. Ayrıca yöneticilerin bakış açılarını inceleyen bu çalışmanın yanı sıra müşteri açısından dijital turizm ile ilgili araştırma yapılabilir. 


\section{Introduction}

Tourism is considered as an important sector that shapes the world and is associated with social and economic development. For this reason, it is noted that many tourist centers have started to create their tourism plans, focusing on different tourism product/products (Giampiccoli \& Saayman, 2014: 1667). Intensive use of data in the tourism sector has led to dependence on information and communication technologies and digital transformation has been inevitable for tourism (Benckendorff et al. 2014; Koo et al., 2015: 100).

A new era, Industry 4.0, has brought many changes to our lifestyle, economy and society and has led us to use next-generation technologies such as 'internet of things', 'artificial intelligence', 'virtual reality' and 'robots' (Bahar et al., 2019: 74). Mobile apps personalize the customer experience by increasing reality and increase the speed at which generation $\mathrm{Z}$ fits into next-generation technologies, especially the frequent presence in tourism mobility. It is thought that that new-generation technologies will have active roles in the tourism industry (Palumbo et al., 2013).

Globalization is accelerating and changing technology is essential for businesses to survive in an intensely competitive environment. New strategies have been developed when changing customer requests and needs are added to this situation. A new concept of customer experience has emerged that attaches importance to the customers and their feelings and wants to ensure that the customers have permanent experiences. Customer experience applications, which have gained importance in various service sectors are considered and implemented by many businesses (Yeşilot \& Dal, 2019: 265).

In the $21^{\text {st }}$ century, the power of consumers has gradually increased and the business that takes into account the consumer is replaced by the phenomenon of the business that the consumer manages (Fournier \& Lee, 2009). Developing technology and the use of social platforms have put the consumer in a strong position. Changes in consumer supply and demand are observed with digitalization. The tourism sector has also had to adapt to this change. Digitalization is an important step for tourism enterprises, countries or regions to achieve success in the sector (Güven et al., 2019: 2).

Digital tourism has ceased to be local in recent years and has started to gain importance on a global scale. For example, functions such as comments made by a person in any social environment, photos shared and a blog (blog) take place in the social media environment. These functions have an important place in the tourism sector for both the business and the customer (Başaran \& Mercan, 2019: 2). Ay (2009: 117-136) stated that social and digital platforms increase their power day by day and it will be beneficial to integrate these elements into businesses. Aktan and Koçyiğit (2016: 64) revealed that digital 
and social platforms are new technological tools that significantly affect the behavior of individuals in tourism activities.

Digitalization in the accommodation sector also positively affects customer satisfaction, loyalty and customer service perception (Sayın \& Karaman, 2019: 19). With the innovation brought by digitalization, customers can have the opportunity to experience virtual reality on the internet. In this way, tourism businesses have the opportunity to present their promotions to customers more easily (Mil \& Dirican, 2018: 6).

In this study, the aim is to determine the perspectives of hotel managers on digital transformation in tourism and to show what applications hotel businesses do or want to do in digital transformation. In this context, qualitative research method was used in the research and data was obtained by semi-structured interview technique. The study aims to contribute to digital transformation in the tourism sector by determining the perspectives of hotel managers and evaluating their views to decide whether accommodation businesses have sufficient potential of digital tourism.

\section{Literature review}

Looking at human history, there are four breaking points that have made devastating impact. The first of these is the period of the Agricultural Revolution, when nomadic societies engaging in hunting and gathering settled and started agriculture. The second is the Industrial Revolution in which the concept of workers was formed. The fact that muscle power was replaced by machine power led to the formation of the working class. With the transition to factory production, cheaper and quality goods began to be produced. The new period in chronological flow coincides with the third Industrial Revolution and the period of technological transformations observed in the fields of production, processing and transfer. Digital transformation in production and service has emerged with technological innovations (Doğru \& Meçik, 2018: 1582).

There are various definitions of digital transformation. The impact of digital transformation and information-communication technologies in all areas of life also points to Industry 4.0, which we hear very often today. Digital transformation is also expressed as the transformation of the business world by adopting digital technologies (Yankın, 2019: 15), and industrial and social transformation (Büyükuslu, 2018: 11). Digital transformation is not only technical, but also defined as ways of thinking, daily habits and career transformation (Acungil, 2018: 19). In addition, it is an important tool for making things easier thanks to practical applications (Telli Yamamoto, 2018: 1), increasing the level of welfare and global development (Aydin, 2018: 13). 
With the digital transformation, the factors that trigger the infrastructure and components in the Industry 4.0 era are big data analysis, smart robots, simulation, internet of things, cyber security, cloud system and virtual reality (TÜSIAD, 2016). With the effect of Industry 4.0, one of the sectors where digital transformation is felt most is the information sector. Areas such as cloud computing, mobile applications, gaming and cybersecurity are increasingly important in this sector (Türesin Tetik, 2018: 260).

The digital transformation movement, with changing customer and consumer behavior, increasing technology progress and digitalization, has led businesses to question the way they do business, their business models, their products and services and the experience they provide to their customers (Deloitte, 2016). For this reason, digital transformation has also had an impact from a social point of view. Bedir expresses these effects below (2017: 48):

- Information production speed: After digital transformation, the production and circulation of information have been easier and faster. This simply leads to the formation of different people whose accuracy, reliability and applicability have not been tested, and who feed on a large number of sources.

- Technology production: The fact that technology has become powerful enough to shape human behavior shows how powerful technology has become.

- Time consumption and reality: The time we spend in the virtual world causes us to move away from the physical world, which in a sense allows for a situation where digital reality is more valuable, more realistic, more traceable than physical reality.

- Information petroleum: "The new petroleum of the digital world is knowledge". It is necessary to make this existence a fundamental awareness of all humanity.

Along with the areas mentioned above, hotels, restaurants, museums, airports and train stations are considered very important areas for testing robots and self-service technologies that come into our lives with digital transformation (Ivanov \& Webster, 2017). Robots and artificial intelligence applications that most hotel chains care about and start using in certain areas contain a lot of information, can undertake and automate more tasks than we can. They can as well accelerate check-in operations. These are only a fraction of the numerous contributions they make to tourism (Yalçın Kayıkçı \& Kutluk Bozkurt, 2018: 58).

Along with the intensive use of information in the tourism sector, interest in information and communication technologies has increased and the use of digitalization for tourism has also become inevitable (Benckendorff et al., 2014; Koo et al., 2015: 100). Today, the widespread use of mobile devices, 
especially the smartphone and many unknown applications, provides a unique connection and access to the internet from anywhere (Wang \& Xiang, 2012: 309).

With digitalization, new situations have been added to the value chain of tourism activities, the balance of existing situations has changed, and there has been a decrease in the number of jobs and transactions performed (Dredge et al., 2018). Change, which started with smart tourism applications in particular, has introduced the concept of smart tourism destinations with the development and change of smart cities (Boes, 2015: 11). In the literature on smart tourism destinations, there is a great effort in the sector to improve tourism service processes and increase tourist production by using information and communication technologies of these tourism destinations (Wang \& Li, 2013).

Increased internet usage due to the popularity of many accommodation businesses, transport companies and travel agencies have begun to include internet technologies, marketing and communication channels (Buhalis \& Law, 2008: 611). Most businesses use information communication channels both to market the destination and develop the business, as well as to increase competitiveness (Güleç, 2016: 7).

Big data is an important element for the concept of digital tourism. Big data is a new concept that makes it possible to identify different volumes of data that cannot be processed using traditional database techniques and it contains a variety of digital content (Gahi, Guennoun \& Mouftah, 2016: 953). Among the sources that feed big data, there are many sources such as smart phones, tablets, computers, sensors, medical equipment, interactions in social networks, simulation and scientific research that provide solutions to many areas (Schneider, 2012: 6).

Augmented reality (AR) and virtual reality (VR) technologies, which are among the most important modern technological developments affecting the accommodation sector, are highly effective tools (Neuburger et al.,2018). Especially in hotel businesses, these applications are more important. Because the abstract weight of the products offered in these enterprises increases the importance of prior experience (Kabaday1, 2020: 465).

Augmented reality and virtual reality improve the tourist experience and help tourists access the necessary information. It also provides important facilities for the dynamic, high interaction and fun realization of the service required by the sector (Keckes \& Tomicic, 2017).

With big data technologies, it is possible to identify the needs and manage the expectations of customers in this sector and add to their experience. From this point of view, the role of big data in the planning and organization of the 
tourism sector is important (Esen \& Türkay, 2017: 92). Therefore, businesses that want digital tourism to provide a sustainable competitive advantage should be able to ensure efficient management of social media, big data and of course, all digital applications (Mariani et al.,2016: 327).

\section{Methodology}

In this study, a qualitative research method was applied. Although quantitative studies are generally applied in the field, this method was chosen because there are relatively few qualitative studies on this subject and so that the indepth views of all actors can be reached. In addition, it is aimed to contribute to a quantitative research study on this topic. Purpose of applying qualitative research method, in general, is that this method allows the researchers to examine the meanings arising from the participants' experiences systematically, to provide sensitivity to the natural environment, to determine perceptions, to have flexibility in the research pattern and to have a deductive analysis (Akıncı \& Sönmez, 2015: 103). Interview technique is designed to gain indepth knowledge in accordance with the themes contained in the identified questions (Altunay et al., 2014: 66). Also, in the data collection process, a semistructured interview pattern was preferred, especially to increase the validity and reliability of the research. Because long-term interaction is the best way to ensure credibility in qualitative research, a semi-structured interview is a good tool to rearrange questions or discuss the relevant topic (Baltac1, 2019: 370). In this way, an environment is provided in which participants contribute on the research application. However, to prevent communication breakdowns, to make it more fluid, to avoid data loss, while interview forms were sent, first, a preliminary interview was done by phone and then a detailed explanation was made before the e-mail was sent. The expressions found in the interview forms are carefully selected, in the interview questions section when preparing the form (Atay et al., 2019). In the information form about applications that can be used in hotel enterprises (Yazıcı Ayyıldız \& Ayyıld1z, 2020), their work was used, but no guidance was allowed.

Büyüköztürk and colleagues (2014: 80) described the population as a large group formed by all kinds of living or inanimate beings needed to answer questions about the subject being investigated. The population of the research was considered as middle, upper and luxury segment hotel enterprises in Istanbul province. In this context, the middle, upper and luxury segment hotel managers in Istanbul province were intervieved.Under the light of this information, the sample can be defined as a group of units or elements selected from within the research population by any method suitable for the purpose and capable of representing the population universe (Ural \& Kıllç, 2006: 35). In this context, the population of the research is considered as middle, 
upper and luxury segment hotel enterprises in Istanbul province. The reason for determining Istanbul as the population (Horwaht HTL -Hotel, Tourism and Leisure- Turkey Chains and Hotels Report, 2019: 5) is based on the hotel rankings table by size in Turkey. A total of 35 chain hotels in Istanbul, local and international, formed the universe of Istanbul province in this research. In the study, judicial (deliberate) sampling method was used in the study because it was thought that the appropriate answer to the determined research problem would be found. In this context, a total of 18 hotel managers, local and international, were interviewed in Istanbul province. Another reason for determining middle, upper and luxury segment Hotel Enterprises in Istanbul as the population is that they are more professional, open to innovation, have strong capital and accessibility to these hotel enterprises is fast and convenient, also there is more digital use in these enterprises.

Şencan, (2005: 501) states that validity and reliability in qualitative research can be achieved within the framework of four criteria: credibility, transferability, strength and confirmability. In order to ensure reliability in this study, the opinions of experts on the subject were taken. Two of the experts who conduct the reviews on the subject are professors and the other one is an associate professor. Their fields of study are smart tourism, digital tourism and qualitative research methods. Given the validity dimension, the interview questions related to this study were first examined by experts and the questions were delivered to three academicians and a hotel manager. The role of the researcher in the research process is clearly defined. In addition, detailed information about data collection, processing, analysis, interpretation and achieving results is provided. In order to ensure the validity of the study, the procedure of data gathering is explained and the data obtained were reported and explained in detail. The data obtained in the study were analyzed by descriptive analysis technique.

It was ensured that the results obtained are compatible, meaningful and consistent with the conceptual framework (Yıldırım \& Şimşek, 2006). In addition, appointments were made in advance from the hotel managers of the middle, upper and luxury segments involved in the meeting and interviews were conducted on the set date. The interviews were made between 01.05.2020 and 25.07.2020. In addition, the statements of the interviewees were recorded in writing to ensure the reliability of the interviews. In addition, since the answers of the participants were reached by e-mail due to the Covid-19 outbreak, written notes about their statements were recorded digitally. As a result of these interviews, 72 pages of data were obtained from 18 interview forms. 


\section{Findings and discussion}

This section will focus on the findings of this study. Two sets of questions were directed to the managers of middle, upper and luxury segment hotels. The first set of questions were about the demographic information of the managers and the other set of questions were about the research. In the first part, 11 questions were asked to the participants. The questions in the second part are to reveal the thoughts and evaluations of hotel managers about the applications that can be used in hotel businesses.

\section{Demographic information about participants}

Demographic information about hotel managers is given under this heading. Demographic information includes gender, age, marital status and educational status. In this context, information about the 18 participants included in the study is given in Table 1.

Table 1: Demographic information for participants

\begin{tabular}{ccccc}
\hline Participants & Gender & Age & Marital Status & Educational Status \\
\hline 1. Participant & Male & 42 & Married & Postgraduate \\
\hline 2. Participant & Male & 48 & Married & Undergraduate \\
\hline 3. Participant & Male & 43 & Married & High school \\
\hline 4. Participant & Male & 39 & Married & Undergraduate \\
\hline 5. Participant & Male & 24 & Single & Undergraduate \\
\hline 6. Participant & Male & 32 & Married & Undergraduate \\
\hline 7. Participant & Male & 35 & Single & Postgraduate \\
\hline 8. Participant & Male & 43 & Married & Undergraduate \\
\hline 9. Participant & Female & 33 & Single & Undergraduate \\
\hline 10. Participant & Male & 43 & Married & Undergraduate \\
\hline 11. Participant & Male & 45 & Single & Undergraduate \\
\hline 12. Participant & Male & 39 & Married & Undergraduate \\
\hline 13. Participant & Male & 35 & Married & Undergraduate \\
\hline 14. Participant & Male & 45 & Married & Postgraduate \\
\hline 15. Participant & Male & 36 & Married & Undergraduate \\
\hline 16. Participant & Female & 30 & Married & Undergraduate \\
\hline 17. Participant & Male & 42 & Married & Undergraduate \\
\hline 18. Participant & Female & 31 & Married & Postgraduate \\
\hline
\end{tabular}

According to this information, when table 1 is examined, it is seen that 15 participants are male and 3 are female and their ages vary between 24 and 48 . 14 participants were married and 4 participants were single. In educational cases, 13 participants have a bachelor's degree level, while 4 of them receive a postgraduate degree. Looking at table 1 , it is seen that the remaining 
1 participant is a high school graduate. In addition, the high use of digital technologies in middle, upper and luxury segment hotels and the fact that these businesses are more professional are important in determining the age group and at what educational level of the managers in these businesses. Therefore, it has been concluded that the majority of the middle, upper and luxury segment hotel managers have a bachelor's degree and higher level of education.

\section{Views on what technology means for tourism industry and its sub-sectors}

18 participants examined the views of the participants on the question "What does technology mean for the tourism industry and its sub-sectors?" and the technology from the point of view of the tourism industry

P13 "Technology also provides high quality and fast service and savings".

P9 "Technology for the tourism industry is indispensable and a process that must always be adapted".

P11 "It has become an indispensable element for today and the future for faster service delivery, both for sub-sectors and when providing face-to-face guest services".

P15 "As of now, people who have bought their holidays and plane tickets in the past by going to an agency can now make these transactions or even comparisons with a click at any time with the phone in their hands. It is evolving in a different direction in the sector, even an online department is being established in some hotels, so even in the Covid-19 time, the technology has a wide and indescribable impact not only in these and similar sectors, but also in the entire area

All participants expressed their views that technology is a must for the tourism industry. According to the opinions received from the participants, they emphasized the importance of technology together with the customer experience theme. Accordingly, Pine \& Gilmore (2012) drew attention to the importance of customer experience, noting that this element should appeal to five senses, feelings and mood, creativity and cognitive functions, behavior and cultural and social groups. In this context, it is understood how important the customer experience is for the tourism sector.

\section{Views on how to achieve digital transformation in the business}

The question "How can the digital transition be achieved in your business?" was asked to the participants in the study, noting that 18 participants have transitioned to digital transformation as a business,

P8 "The transition has been achieved, and we continue the process in expanding the transition".

But participant 2, participant 13, participant 14, participant 15 and participant 18 , referring to the fact that the covid-19 pandemic has prepared businesses for a new order, said: 
P2 "Many of our systems are currently up to date, but today there is a pandemic fact, and this pushes us to other methods such as QR-coded menu systems, and contactless check-in".

They presented examples of more frequent use of technology with the pandemic process in hotel enterprises and emphasized the theme of the pandemic. In order to ensure sustainability, applications must be made to increase the satisfaction of both businesses and customers (Koçoğlu Sazkaya, 2019: 2). In this context, based on the responses of managers to the continuation of the process, it is seen how vital the concept of sustainability is in digital tourism due to its effect during the pandemic.

\section{Views on the question of what the most important difficulties-are}

Of the 18 participants, 15 said that there will be difficulties in personnel training and budget, cost issues in general,

P7 "I believe that the human factor and personnel should be prepared, and another barrier is economic strength".

P12 "The most important difficulty is the cost. Technology is useful, but it is a big item that costs so much." they indicated difficulty with their statements.

The remaining two participants stated that there will be difficulties in the transition process regarding the compliance process of the staff and the customer as follows:

P3 "It would be correct to express it as the adaptation process for our incoming guests and employees to get used to the process".

P17 "The adjustment process is a significant challenge. Especially the ability to transfer innovation to staff and customers".

Participants emphasized the theme of adaptation process with their responses. Harmony is the ability to establish and maintain a balanced relationship between the characteristics that a person has and the environment in which they live (Doğan et al., 2008: 47). Based on this, ensuring a balance in customer and technology can form the basis of success in the adaptation process.

Finally, according to Participant 9, the answer is as follows:

P9 "Since it is the service sector, the transition of every department to digital transformation can eliminate the services such as smiling face and hospitality offered by hotels. Therefore, I think that digital transformation is not possible for every department in hotel enterprises".

Emphasizing the theme of the transition to digital process between departments, he stated that the transition to digital transformation in the service sector will not be fully achieved in outsourced departments such as reception, housekeeping, food and beverage, management and security (Rodrigez \& Robaina, 2004). In this 
context, it is understood that with digital transformation, the transition process will be different for each department and the process will be provided in stages.

\section{Views on planned information technology applications that the business is} involved in

Eighteen participants stated that they generally used P2 "Intelligent building systems, the ability to provide products and menus suitable for the customer, purchase intelligent stock system (ESP) and in-room motion sensor systems."

Since 3 of the 18 participants are international hotel chains, they stated that they can implement new information systems in accordance with the brand's direction as follows:

P9 "Since it is a global business, the primary goal is to implement the applications planned simultaneously by all enterprises in the world".

3 of the remaining 15 participants stated that they used Opera software. It is found out that the other 12 participants used different information technologies. According to the responses of the participants, they emphasized the theme of the use of various information technologies. In particular, it is important that most businesses use different information communication channels both in terms of marketing the destination and developing the business, as well as in terms of increasing competitiveness (Güleç, 2016: 7). As can be seen from the responses of the managers, information communication channels have become very important to ensure digital transformation in the sector.

\section{Views on the current infrastructure status of the business in information technology}

The general opinion of the participants is that their infrastructure is very healthy and that there is a unit that monitors them:

P2 "Our existing infrastructure is updated as technology changes. We are neither lacking nor more. Therefore, all systems are used optimally. Periodic maintenance is programmed regularly".

P5 "Maintenance is carried out at regular intervals to provide a healthy service on infrastructure.", "We have no problems with our infrastructure".

However, Participant 11 emphasized the theme that infrastructure should be improved in the remaining areas by saying: "Though it can be sufficient in points where direct service is provided to the guest (such as reception), it can be better in the background areas". In line with the opinions, digitalization is an important step in increasing the success of tourism businesses, countries or regions in the sector. (Güven et al., 2019: 2). For this reason, it is important for businesses to have a strong infrastructure in order to transfer their digital applications flawlessly. 
Views on the question of which technologies they consider correct/ appropriate to use

Participants stated that as a requirement of being an international hotel chain, they follow information technology practices in Turkey or abroad and care about the management's decision as follows:

P1"Our business is strict about implementing the latest technology used by the chain hotel brand to which it is affiliated because our most important criterion when using technology is customer satisfaction". All the participants have stated opinions close to his statement.

P12 emphasized that the hotel establishments are international, the systems are generally used with a foreign language and that the staff with insufficient language skills have a problem while using the systems by saying: "Since it is an international chain, the systems determined by the central management are used. In general, the systems are used in English. Personnel with insufficient English may have problems. Sometimes the systems you use may conflict with some of the legal rules of the country. There may be problems in these matters". Cengiz (2011) also drew attention to the need to follow the current practices in the world in order to establish cooperation between public sector and private sector that follows global developments. He also pointed out that following the global practices is very important to transfer foreign innovations in tourism to the local. Based on this, it is thought that following up the global practices will be positive for businesses.

\section{Views on the question "What are the benefits or harms of digital transformation to the staff in your business?"}

The opinions of 5 of the 18 participants are as follows: "Employees use digital transformation to open new fields for themselves. This means that it contributes to personal development. It provides convenience in their work and motivates them".

P9 "I think the biggest benefit is saving time. I don't think there can be any harm".

P10 “Digital transformation doesn't hurt. It's done to make work easier. This makes it easier for staff".

13 participants expressed opinions that it would be both beneficial and harmful. Opinions that it will benefit;

P1 "Guest satisfaction, you get ahead of your competitors, you increase your brand value".

P5 "Digitalization will help personnel gain new knowledge by opening the door to a new world where they are far from".

P11 "Staff are more aware of new technologies, and when they become managers in the future, they put these technologies into practice and can more easily track innovations". 
Opinions that it will be harmful;

P4 "Time is wasted on staff who do not want to adapt or are forced into this process".

P8 "There will be difficulties for those who are not inclined to use technology or have no access".

P11 "Communication and connection between employee and guest can be weakened".

Based on all statements, they emphasized the theme that digital transformation will weaken the bond between employment, innovation and personnel, as well as customers and personnel. Along with the ever-decreasing traditional hierarchy of orders and commands, those working in a transforming environment need to be empowered, in addition, there is an expectation from employees to be creative and to accept responsibility (Quinn \& Spreitzer, 1997: 37). However, the contribution of today's businesses - which are under the influence of high customer expectations, increasing globalization movements and technology - to employees in this process is also very important.

Views on the question "What will be the benefits of digital conversion applications in terms of marketing function?"

In general, participants stated that they will contribute to the marketing function as follows:

P10 "Very useful in terms of marketing. For example, you are using an ERP system for sale. Programs (called artificial intelligence) that evaluate which company or person you have called when you should call, and accordingly issue warning messages to staff, provide incredible benefits for your company by enabling one person to employ, not 3 people."

P9 "It is very useful in terms of reaching more audiences / transferring information quickly and effectively using the social media channel." expressions in the form like these show that participants emphasize the themes of competition and quick access to customers through marketing. With increasing competitive conditions and technology, businesses have also forced marketing to undergo transformation in order to be closely involved with their customers (Akçi, 2018: 139). When the digital concept is evaluated in terms of its marketing function, it is seen that transferring information quickly and effectively will benefit businesses.

Views on the question "What strengths and weaknesses will be in your business with digital transformation?"

Participants generally expressed: P1 "With digitalization, guest satisfaction increases, costs decrease and your brand value increases. Weakness; maybe a robot can give the coffee that the guest wants, but the guest is not 100\% satisfied because there is no human emotion and touch to the guest. The guest wants to feel special." 
$\mathrm{P} 4$ "While its strengths are minimizing errors, as a weakness, it will be difficult to ensure customer satisfaction in all of the customers."

P11 "Being an international chain is a strong aspect of our business. But with digital transformation, staff shortages will be our weakness." by giving such answers, they stated that they will have both strengths and weaknesses with digital transformation.

Some other participants used the following statements:

P9 "Staff costs can be reduced, solving many issues quickly and effectively / meeting guest requests can increase guest satisfaction of the enterprise. I can not think of any weaknesses."

P10 "Digital transformation will not provide weakness to any business. It is important that the digital transformation is adopted by the staff and by the guests." they responded that digital transformation will provide the business with strengths but not weaknesses. Participants emphasized the theme of customer satisfaction. Customers have been more selective in the face of products sold, services offered and technological development in a competitive environment. Because of this, product development and diversification, to realize these needs, which predict the current and future needs and expectations of the customer. Many strategies are very fast and the competitiveness of leading companies is higher (Acuner, 1998: 10).

\section{Views on the question "What the opportunities and threats will be in your business with digital transformation?"}

In line with the-views on what opportunities may be created in businesses with digital transformation;

P1"We get ahead of competitors and the brand value of the business increases, different sales markets will occur, more employee business opportunities are created in the computing department, have a cost-reducing effect, we become faster and easier to reach competitors in the market, and can significantly increase the profit share." they have responded that there may be opportunities like this.

Participants generally answered the issue of what threats may occur in businesses with digital transformation as follows;

P12 If we reduce the human factor, the business loses guests, control from the social platform must be very well maintained, applications may collapse, there will be a threat to the employment of personnel, good and not fully utilized products harm the business instead of benefit, increasing costs and causing information theft and cyber attack".

As can be seen from the statements, they emphasized the theme of information theft and cyber attack. With the digital transformation, new cyber attack methods have started to be used that are far ahead of traditional methods, 
and the increasing rapid developments in computer and internet technologies make it difficult for administrations to monitor the virtual world and often leave the administrations helpless and inadequate (Gürkaynak \& İren, 2011: 264). For this reason, administrations will be able to contribute to enterprises by using new methods instead of traditional methods in the fight against malicious practices around the world.

\section{Views on the question "What can be done to achieve digital transformation in hotel enterprises?"}

In general, participants in the study gave answers to what can be done to achieve digital transformation in hotel businesses as follows,

K15 "Digital transformation is a long and challenging process and you also need to constantly adapt to the system with new technologies. First, it is necessary to understand this work correctly, it is absolutely necessary to work with business experts, it is also necessary to subscribe to mobile platforms and take reliable measures against cyber attacks and threats via online, data analysis, countless training sessions, and so on".

P1"You must have a good research and development (RED) team, it is necessary to contribute to your development by sending your staff abroad to education and other hotel enterprises, IT ( Information Technology) department consists of a very good team, investors must be convinced to invest in technology, universities must take part in departmental courses related to this field, infrastructure competence must be checked, focused on augmented reality, robot and artificial intelligence applications should be followed and a line of business called digital marketing should be created in the sales department and a professional expert should be employed in this department". In line with these responses, participants emphasized the theme of artificial intelligence. It actually seems that artificial intelligence is a very important element for digital transformation and every field.

\section{Views on applications that can be used in hotel businesses}

Under this heading, participants were asked about digital applications that can be used in hotel businesses now or in the future, and participants mentioned the following applications:

$P 1$ "Thermal camera measuring body temperature at hotel entrance, $Q R$ coded menu, in-room light, curtain, TV adjustment with tablet",

P8 "Applications like Trustyou, Planet21, Bluejeans, Attendify, Iauditor, Yammer, Boxer, Hub",

$P 11$ "Online restaurant reservation system. Guest preferences tracking system, digital menu, online ordering system"

P16 "“360 virtual tour ( 360 degree virtual tour ) applications". The QR menu, the new generation digital menu, are digital applications prepared for cafes and 
restaurants. In addition, Trustyou, which provides information about the hotel on popular social media and reservation sites, Planet21, an environmental and social responsibility program that includes social responsibility topics under health, nature, carbon, innovation, local, employment and dialogue, and other programs mentioned before are some of the important steps of digitalization for hospitality businesses. Virtual reality, which has been entering every field rapidly in recent years, is a technology that gives a real-life feeling with the guidance of the perception mechanism in the body of an environment that does not occur in real life (Kuruüzümcü, 2007: 94). This application, which can provide an advantage in tourism, offers the opportunity to experience a popular environment and/or event that can or may harm without risk.

\section{Results and recommendations}

The aim of this study is to determine the perspectives of hotel managers on digital transformation in tourism. Another purpose of the study is to reveal what applications hotel businesses do or want to do in terms of digital transformation. Considering that the study should be a guide for the people who will do the work after that, a detailed assessment was made in terms of revealing the shortcomings of the enterprises, if any, and reflecting the thoughts of the managers.

In the interviews held with middle, upper and luxury hotel managers, most of the participants stated that the technology contributed to increasing the market share, providing quality and fast service and making savings in terms of what technology means for the tourism industry and its sub-sectors. The participants emphasized the importance of the customer experience theme along with technology. In this direction, digitalization in the accommodation sector positively affects customer satisfaction, loyalty and customer service perception (Sayın \& Karaman, 2019: 19). In this context, it can be concluded that hotel enterprises should give importance to technology in terms of providing these elements and supporting the tourism sector.

Most of the participants replied that they made the transition to digital and continued the process to expand it. In line with the guidelines of the World Health Organization against the new pandemic that endangers public health on an international scale, national administrations also take many measures to protect public health and to come out of the pandemic with as little damage and loss as possible (Acar, 2020: 15). Likewise, the participants stated that many systems are currently up-to-date, but due to the pandemic reality, they are pushing businesses to other methods. They emphasized the pandemic theme, and provided examples that technology, such as "QR coded menu systems, systems such as contactless check-in", will be used more frequently with the pandemic process in hotel enterprises. With the Covid-19 pandemic, it 
is thought that digitalization will make significant contributions to the tourism industry and offer new alternatives.

Personnel expense, which has an important share in the cost factors in accommodation enterprises regarding the most important difficulties / difficulties that hotel businesses will face in the process of transition to digital transformation, will be a more important cost element with the effect of digitalization (Köroğlu et al., 2011: 36). Participants believe that the human factor and personnel should be prepared and there should be economic power. Again, the participants stated that technology is beneficial, but its it is a big expence. Some of the participants also pointed out that the adaptation process is an important challenge, especially in conveying innovation to staff and customers. Participants emphasized the theme of the adaptation process with their answers. Adaptation is the ability to maintain a balanced relationship between the characteristics of a person and the environment he / she lives in (Doğan et al., 2008: 47). Based on this, it is thought that it can form the basis of the adaptation process by balancing customer and technology.

In a tough competitive environment, businesses need to be able to catch up with the information age in order to differentiate with their competitors and protect their place. Therefore, it is very important to establish a solid technology and information infrastructure (Bilgin Sar1, 2018: 33). In the study, the participants were asked questions about the information technologies that their businesses are involved in or are planning. Participants presented examples such as smart building systems, providing appropriate products and menus, purchasing, smart stock system (ESP) and in-room motion sensor systems. They also stated that being an international hotel chain has advantages, and thus they can implement new systems more easily. In this context, it is thought that if digital transformation can be designed within a strategic plan in hotel businesses, it can provide significant contributions and developments.

It has been stated that the current infrastructure of enterprises in information technologies has changed with the digitalization in consumer supply and demand. The tourism sector has also had to adapt to this change. With adaptive businesses and digitalization, it can be an important step to increase the success of countries or regions in the sector (Güven et al., 2019: 2). Therefore, they stated that they tried to strengthen and update their existing infrastructures as technology changes, therefore they use all systems at the optimum level and that periodic maintenance is included in the program. However, one participant expressed an opinion that the remaining services should be improved. In this context, it is concluded that although necessary infrastructure is ready in most fields, there is a lack of infrastructure in some services and detailed infrastructure examinations are required in this regard. 
Regarding what the benefit or harm of digital transformation will be to the personnel in their businesses, the participants stated that the personnel will create new fields for themselves by using technology and contribute to their personal development, it will facilitate their work and create motivation, and stated that the greatest benefit will be saving time. As for the damage; they stated that spending time on staff who do not want to adapt or who forcefully circumvent the process will cause harm, the decrease in the need for personnel with digital innovations will harm the personnel in terms of employment, and also weaken the communication and bond between the employee and the guest. In addition, there were opinions that it would be both harmful and beneficial, and some stated that while putting the personnel in danger in terms of employment, with the new system, the personnel will be able to work in various fields. In this context, 3 different opinions about the issue are reached: 'it will be harmful', 'it will be beneficial' and 'it will be both harmful and beneficial' to the personnel. With the ever-decreasing traditional command hierarchy, employees in the environment in transformation need empowerment, as well as expectations from employees to be creative and accept responsibility (Quinn \& Spreitzer, 1997: 37). However, it is concluded that today's enterprises, which are under the influence of high customer expectations, increasing globalization movements and technology, will also contribute to employees in this process.

Regarding the benefits of digital transformation applications in terms of marketing function, it is known that mass production is now replaced by experience production and/or production according to special requests by offering products and services that take customer requests into account. With the increasing competition conditions, businesses have required to pay close attention to their customers (Akçi, 2018: 139). In this context, they stated that they would be beneficial for marketing, that there are artificial intelligence systems that evaluate which company or person should be called and when, and accordingly, programs that provide warning messages to the staff provided a significant benefit to the business by providing the opportunity to work with a small number of people. It can be understood that artificial intelligence is a very important element for digital transformation and similar fields. In line with these views, considering that digital applications such as artificial intelligence and robots are involved in hotel processing today, it is thought that the use of these systems in the entire tourism sector will provide significant contributions.

Another of the basic services of tourism enterprises is that they have a lot of information for consumers and can deliver this information to them. Therefore, it has become very important for tourism enterprises to use information technology up-to-date and actively (Mutch, 1995). In this study, in general, the opinions of the participants stated that hotel businesses have the appropriate potential in all aspects for digital transformation in tourism and that certain digital applications 
and information technologies are available. However, it has been stated that detailed studies and practices on the subject need to be examined and time is needed to ensure digital transformation in the tourism sector.

Based on all these, suggestions for accommodation businesses may be as follows. They can transfer digital applications in their companies to the customer through effective promotions and advertising. At the same time, applications installed on mobile phones, such as the QR coding system, can be developed as an information tool, allowing customers to access all information before arriving at the accommodation business. In addition, necessary training meetings can be organized for staff on the sustainability of digital tourism and interesting digital designs that will allow them to share on social platforms to attract the customer's attention can be made.

Recommendations for researchers can be listed as follows. Up-to-date and extensive academic studies can be done to contribute to the literature on digital tourism. At the same time, by taking advantage of the studies in the field of digital tourism, review work can be carried out on a sectoral basis in enterprises where digital transformation is on a larger scale. In addition, this study, which examines the perspectives of managers research on digital tourism can be carried out from the customer perspective. Different scientific studies on digital tourism can be done in different cities and regions. Finally, this research, conducted within the framework of qualitative research, can also be studied by conducting quantitative research. After that, different research topics can be created by comparing both studies.

\section{References}

Acar, Y., (2020). Yeni koronavirüs (cov1d-19) salgını ve turizm faaliyetlerine etkisi, Güncel Turizm Araştırmaları Dergisi, 4 (1), 7-21.

Acungil, M. (2018). 24 Soruda Dijital Dönüşüm, Tuti Kitap.

Akçi, Y. (2018). Değişen pazarlama anlayışı yeni pazarlama yaklaşımlar, Gazi Kitapevi.

Akıncı, Z. \& Sönmez, N. (2015). Engelli bireylerin erişilebilir turizm beklentilerinin değerlendirilmesine yönelik nitel bir araştırma, Anatolia: Turizm Araştırmaları Dergisi, 26 (1), 97 - 113.

Aktan, E. \& Koçyiğit, M. (2016). Sosyal medya'nın turizm faaliyetlerindeki rolü üzerine teorik bir inceleme, Sosyal Bilimler Dergisi ICEBSS Özel Sayısı, 62-73.

Altunay, E., Oral G. \& Yalçınkaya, M. (2014). Eğitim kurumlarında mobbing uygulamalarına ilişkin nitel bir araştırma, Sakarya University Journal of Education, 4 (1), 62-80. 
Atay, L., Yalçınkaya, P.\& Bahar, F. (2019). İstanbul'daki akıllı otel uygulamalarının değerlendirilmesi, MANAS Sosyal Araştırmalar Dergisi, 8 (1).

Ay, L., (2009). Bilgi teknolojisindeki gelişmelerin seyahat acentalarına yansımaları; Online seyahat acentacılığı, Sosyal Ekonomik Araştırmalar Dergisi, 17, 117-136.

Aydın, A. (2018). Seçili ülkelerde kamuda dijital dönüşüm, başarı faktörleri ve güncel eğilimler, Kamuda Dijital Dönüşüm, Kriter Yayınevi.

Bahar, M., Yüzbaşıoğlu, N. \& Topsakal Y. (2019). Akıllı turizm ve süper akıllı turist kavramları 1şığında geleceğin turizm rehberliğine bakış, Aydın Adnan Menderes University Journal of Travel and Tourism Research, 14, 72-93.

Baltacı, A. (2019). Nitel araştırma süreci: Nitel bir araştırma nasıl yapılır?, Ahi Evran Üniversitesi Sosyal Bilimler Enstitüsü Dergisi (AEÜSBED), 5(2), 368-388.

Başaran, T. \& Mercan, O. (2019). Sosyal medyadaki fotoğraf ve özçekimlerin turizm pazarlaması açısından önemi: İstanbul'a yönelik bir çalışma, 1. International Congress on Dijital Transformation in Tourism I-DIGIT -19, 115-128.

Bedir, B. (2017). Dijital dönüşüm ve etkileri, Tarmer Çalıştayları-2, İAÜ Toplumsal Araştırmalar Uygulama ve Araştırma Merkezi, IAÜ Yeni Medya Uygulama ve Araştırma Merkezi, 48-51.

Benckendorff, P., Sheldon, P. \& Fesenmaier, D. R. (2014). Tourism information technology, Oxford: CAB International.

Boes, K. (2015). Smart tourism destinations: smartness as competitive advantage, In ENTER2015 PhD workshop research proposals., 11-15.

Buhalis, D. \& Law, R. (2008). Progress in information technology and tourismmanagement: 20 years on and 10 yearsafterthe InternetThestate of eTourismresearch, Tourism Management, 29 (4), 609-623.

Büyüköztürk, Ş. Şekercioğlu, G. \& Çokluk, Ö. (2014). Bilimsel araştırma yöntemleri (18. Bs.), Pegem.

Büyükuslu, A.R., (2018). Dijital dönüşüm, D\&R Kitapevi Yayınevi ve Dağıtım

Cengiz, C. (2011). Yeni nesil turizm geliyor, Turizm Güncel, 04 Ocak 2020 tarihinde http://www.turizmguncel.com/makale/ yeninesilturizmmodeligeliyorm425.html adresinden erişildi.

Deloitte, (2016). Türkiye'deki dijital değişime ceo bakışı, TÜSİAD, 03 Ağustos 2020 tarihinde https://tusiad.org/tr/yayinlar/raporlar/item/8867-tu-rkiyedeki-dijital-deg-is-ime-ceo-bakis-i-raporu adresinden erişildi. 
Dirsehan, T. (2012). Müşteri deneyimi tasarımı ve yönetimi. Hiperlink Yayınları.

Doğan, S., Kelleci, M., Sabancıŏ̆ulları, S., \& Aydın, D. (2008). Bir ilköğretim okulunda öğrenim gören çocuklarda ruhsal uyum sorunları, TSK Koruyucu Hekimlik Bülteni, 7(1), 47-52.

Doğru, N. B. \& Meçik, O. (2018). Türkiye'de endüstri 4. 0'ın işgücü piyasalarına etkileri: Firma beklentileri, Süleyman Demirel Üniversitesi İktisadi ve İdari Bilimler Fakültesi Dergisi, 23, (Endüstri 4 . 0 ve Örgütsel Değişim Özel Say1s1), 1581-1606.

Dredge, D., Phi, G. Renuka, M., Eóin, M. \& Popescu, E.S.(2018). Digitalisation in tourism, the european commission's easme final report, Denmark.

Fournier, S. \& Lee, L.(2009). Getting brand communities right, harvard business review, 04 Ocak 2020 tarihinde https://hbr.org/2009/04/getting-brandcommunities-right adresinden erişildi.

Gahi, Y., Guennoun, M. \& Mouftah, H. T. (2016). Big data analytics: security and privacy challenges, 2016 IEEE Symposium on Computers and Communication (ISCC), 952-957.

Giampiccoli, A. \& Saayman, M. (2014). A conceptualization of alternative forms of tourism in relation to community development, Mediterranean Journal of Social Sciences, 5 (27), 1667-1677.

Güleç, E. (2016). Kullanım ve doyumlar yaklaşımının sosyal medya kullanım niyeti ve turistik deneyim üzerindeki etkisinin belirlenmesi, [Yayınlanmamış yüksek lisans tezi], Balıkesir Üniversitesi.

Gürkaynak, M. \& İren, A.A. (2011). Reel dünyada sanal açmaz: siber alanda uluslararası ilişkiler, Süleyman Demirel Üniversitesi İktisadi ve İdari Bilimler Fakültesi Dergisi, 16 (2), 263-279.

Güven, A., Özçelik, G. \& Kartal, O. (2019). Turizm fakültelerinde dijitalleşme eğilimi, 1. International Congress on Dijital Transformation in Tourism I-DIGIT-19, 155-167.

Horwaht HTL (Hotel, Tourism and Leisure), (2019). Türkiye zincirler ve oteller raporu, 05 Ocak 2020 tarihinde https://turkey.cms-horwathhtl. com/wp-content/uploads/sites/10/2019/03/HHTL_T\%C3\%BCrkiye_ Raporu_2019.pdf adresinden erişildi.

Ivanov, S. \& Webster, C. (2017). Adoptation of robots, artificial intelligence and service automation by travel, tourism and hospitality companies a costbenefit analysis, International Scientific Conference Contemporary TourismTraditions and Innovations, October, Sofia University, 19-21. 
Kabadayı, M. (2020). Otel işletmelerinde sanal gerçeklik ve artırılmış gerçeklik uygulamalar1, Journal of Travel and Hospitality Management, 17(3), 464479.

Keckes, A. L., \& Tomičić, I. (2017). Augmentedreality in tourism-researchand applications overview, Interdisciplinary Description of Complex Systems: INDECS, 15(2), 157-167.

Koçoğlu Sazkaya, M. (2019). Dijital sürdürülebilirlik, işletmelerin kaçınılmaz yolculuğu dijital dönüşüm, Beta Yayıncılık, 259-288.

Koo, C., Gretzel, U., Hunter, W.C. \& Chung, N. (2015), The role of it in tourism, Asia Pacific Journal of Information Systems, 25 (1), 99-104.

Köroğlu, Ç., Biçici, F. \& Sezer, D. (2011). Otel işletmelerinde maliyet kontrolünün rekabet üstünlüğüne etkisi, İşletme Araştırmaları Dergisi, 3(1), 33-48.

Köroğlu, Ç., (2012). Stratejik maliyet yönetimi kapsamında sürece dayalı faaliyet tabanl maliyetleme yönteminin analizi ve bir otel işletmesinde uygulama, [Doktora tezi], Adnan Menderes Üniversitesi.

Kuruüzümcü, R. (2007). Bir dijital ortam ve sanat formu olarak sanal gerçeklik, Sanat Dergisi, 12, 92-96.

Mariani, M. M., DiFelice, M. \& Mura, M. (2016). Facebook as a destination marketing tool: evidence from italian regional destination management organizations, Tourism Management, 54, 321-343.

Mil, B. \& Dirican, C. (2018). Endüstri 4.0 ve turizme etkileri, Disiplinlerarası Akademik Turizm Dergisi, 1 (3), 1-9.

Mutch, A. (1995). It and small tourism enterprises: A case study of cottagecottage letting agencies. Tourism Management, 7 (16), 533-539.

Neuburger, L., Beck, J., \& Egger, R. (2018). The 'Phygital' tourist experience: The use of augmentedand virtual reality in destination marketing, In Tourism Planning and Destination Marketing, 183-202.

Palumbo F., Dominici G. \& Basile G. (2013). The culture on the palm of your hand: how to design a user oriented mobile app for museums, In L. Aiello (Ed.), Management Of Cultural Products: E-Relationship Marketing And Accessibility Perspectives, IGI Global, 224-243.

Pine, J. \& Gilmore, J. (2012). Deneyim ekonomisi (Güncellenmiş tekrar basım), Optimist Yayınları.

Quinn R.E. \& Spreitzer, G.M. (1997). The road to empowerment: Seven questions every leader should consider, Organizational Dynamics, 26 (2), 37- 51. 
Rodriguez, T.F.E. \& Robaina, V.P., (2004). Outsourcing and its impact on operational objectives and performance: A study of hotels in canary islands, Hospitality Management, (23), 287-306.

Sayın, K. \& Karaman, A. (2019). Endüstri 4.0 ve turizm 4.0 arasındaki ilişki, Dijital Turizm Sektörün Yeni Geleceği, Aralık, 10-25.

Schneider, R. D. (2012). Hadoop for dummies (special edition), Mississauga, Canada: John

Şencan H., (2005). Sosyal ve davranışsal ölçümlerde geçerlilik ve güvenilirlik, Seçkin Yayıncilik.

Telli Yamamoto, G. (2018). Kamuda dijital dönüşüm ve düşündürdükleri - Kamuda dijital dönüşüm, Kriter Yayınevi, 1-12.

Türesin Tetik, H. (2018). Dijital dönüşüm uygulamalarının kuşaklar açısından değerlendirilmesi - Kamuda dijital dönüşüm, Kriter Yayınevi.

TÜSİAD. (2016). Türkiye'nin küresel rekabetçiliği için bir gereklilik olarak sanayi 4.0, (Yayın no: TÜSİAD-T/2016-03/576). 25 Temmuz 2020 tarihinde http:// www.tusiad.org/indir/2016/sanayi-40.pdf adresinden erişildi.

Ural, A. \& Kılıç, İ. (2006). Bilimsel araştırma süreci ve spps ile veri analizi (Genişletilmiş 2. Bs.), Detay Yayıncılık.

Wang, D. \& Xiang, Z. (2012). The new landscape of travel: a comprehensive analysis of smartphone apps, In M. Fuchs, F. Ricci ve L. Cantoni (Eds.). Information and Communication Technologies in Tourism, 308-319.

Wang, D., Li, X. \& Li, Y. (2013). China's smart tourism destination initiative: a taste of the service-dominant logic, Journal of Destination Marketing $\mathcal{E}$ Management, 2, 59-61.

Yalçın Kayıkçı, M. \& Kutluk Bozkurt, A. (2018). Dijital çağda z ve alpha kuşağı, yapay zeka uygulamaları ve turizme yansımaları, Sosyal Bilimler Metinleri, 1.

Yankın, F.B. (2019). Dijital dönüşüm sürecinde çalışma yaşamı, Trakya Üniversitesi İktisadi ve İdari Bilimler Fakültesi E-Dergi, 7 (2), 1-38.

Yazıcı Ayyıldız, A. \& Ayyıldız, T. (2020). Pazarlama firsatı olarak akıllı turizm: Kuşadası örneği, Business and Management Studies: An International Journal, 8 (1), 599-623.

Yeşilot, F. \& Dal, N.E. (2019). Müşteri deneyimi oluşturma ve deneyimsel pazarlama: İyaşpark alışveriş merkezi (avm) müşterileri ile bir araştırma, Mehmet Akif Ersoy Üniversitesi Uygulamalı Bilimler Dergisi, 3 (2), 263-296.

Yıldırım, A. \& Şimşek, H. (2006). Sosyal bilimlerde nitel araştırma yöntemleri (6. Bs.), Seçkin Yayıncılık. 


\section{Etik kurul onay1}

Düzce Üniversitesi bilimsel araştırma ve yayın etik kurulu tarafından 04.06.2020 tarih ve 2020/101 sayılı etik kurul onayı alınmıştır.

\section{Araştırmacıların katkı oranı beyanı}

Yazarlar çalışmaya 1. yazar \%60, 2. yazar \%40 oranda katkı sağlamıştır.

\section{Çıkar çatışması beyanı}

Bu çalışmada herhangi bir potansiyel çıkar çatışması bulunmamaktadır. 